Quaestio facti. Revista Internacional sobre Razonamiento Probatorio

Quaestio facti. International Journal on Evidential Legal Reasoning N. 2 | 2021 pp. 13-16

Madrid, 2021

Marcial Pons Ediciones Jurídicas y Sociales

ISSN: 2604-6202

Editado bajo licencia Reconocimiento 4.0 Internacional de Creative Commons

\title{
MICHELE TARUFFO, IN MEMORIAM
}

Jordi Ferrer Beltrán

While we were finishing up this second issue of Quaestio facti, the news of Michele Taruffo's death fell upon us like a cold shower. He was undoubtedly one of the most important links in the causal chain that led to the foundation of this first journal dedicated to evidentiary reasoning in the area of the Roman-Germanic legal traditions. It is largely to his merit that evidential issues, which were once neglected and marginalized, are now increasingly at the center of analysis and academic study. Publications have multiplied exponentially, study programs have been created, substantial changes can be identified in judicial reasoning and are registered in case law and, little by little, in legislation itself too.

But none of this had happened yet when Taruffo wrote Studi sulla rilevanza della prova (1970) or his masterful La prova dei fatti giuridici (1992). From then on, and until his death, he authored several books and articles, and always wrote with the clarity and precision of an analytic philosopher. It is no coincidence that, in Pavia, he studied with Amedeo Conte and Uberto Scarpelli (who advised him to focus on the work of logical positivists while he was completing his first monograph) and that he was an avid reader of Giovanni Tarello.

But if there is something that characterized his work, it is his relentless ambition to cross borders. He did it in a physical sense all his life, because he loved to travel and discover remote places, far from the crowds, and venture into jungles for adventure, always in search of archaeological wonders that would allow him to better understand cultural origins and developments. At the table, he enjoyed experimenting all culinary traditions and, above all, chatting with the many friends he had all over the world. He used to say: «Don't invite me to travel, I may very well accept». This ambition to cross borders characterized his academic work too: he wanted to know 
in depth legal institutions and, following the example of his master Vittorio Denti, he always thought that the best way to do it was through the comparative method; he would scrutinize the origins of legal institutions and their cultural contexts, and would know the debates, literatures and case law of other countries, trying to understand why the same problem is faced and solved differently in different countries.

But Taruffo didn't only cross physical-political boundaries between countries and legal systems: he tried to escape the, so to speak, «isolationist» way of working in the legal field. For this reason, he became interested in philosophy, epistemology, sociology and even neuroscience. He had no esteem, in his words, for the «exegetes of article 15, second paragraph, letter a)» of any piece of legislation, who seemed to him to produce short-sighted and uninteresting arguments. Commenting on some of his earliest works, a well-known procedural scholar once said: «Taruffo is very good, but he reads strange things». Michele, instead, loved to debate and, above all, the exercise of thought without restricted limits: «if a problem is serious, it affects everyone or many, regardless of their idiom [...]; if there is a problem only for those who speak a certain idiom, then it is very likely that it is not a serious problem at all» ${ }^{1}$.

I had the opportunity to meet him personally, for the first time, in 1998 at the Italo-Spanish congress of analytic philosophy of law. I had just finished my doctorate, and Paolo Comanducci, to whom I am indebted for this among many other things, introduced me to Michele Taruffo. That same day we decided that I would work on the Spanish translation of La prova dei fatti giuridici. It was a long and tiring job, which lasted almost three years, but during that time we exchanged hundreds of emails and personal conversations; I have learned so much that I had the constant feeling of being very ignorant indeed. I was so impressed with his work that I continue to study those same topics to this day. In our dialogues, which became more and more frequent in the various trips we made together and during his stays in Girona, Taruffo showed a rare combination of assertiveness and intellectual humility. His views were usually blunt, firm and even vehemently expressed (this was his character), but at the same time he was able to take the opposite argument seriously and had no qualms in citing himself as an example of someone who had supported an idea that now seemed wrong. This is what intellectual integrity is all about.

Over the years, his visits to Girona became more frequent and for some time we were fortunate enough to have him working with us for four or five months a year. Here he lectured in our graduate course on civil liability law and contributed from the very beginning to the creation of our graduate course on evidential reasoning, where he taught until his final days. He completely abandoned unnecessary formalities and even allowed himself to be called Michelino by some of our most daring $\mathrm{PhD}$ students; he drank tequila and rum while we sang to the sound of a guitar at the end of our meetings to discuss the progress of our PhD students and their theses.

1 See Taruffo's text below. 
In Girona, as in many other places, he left a real school; and we all hope to honor his teachings.

Almost two months after his premature farewell, I write these first lines about a master and a great friend of mine. A great sadness pervades me, having the feeling of being orphaned. We lost one of the greatest jurists of the last fifty years, someone who profoundly changed the understanding of evidence law in the Roman-Germanic cultural area. This is why we want to dedicate to his memory this issue of the journal, which he inspired in so many ways.

Thanks to the generosity of Cristina de Maglie, Taruffo's wife, and Luca Passanante, we had access to this little unpublished story, in which Taruffo presents an ironically parochial image of lawyers, as an antithesis of the model that he represented. With the permission of Prof. de Maglie, we publish it here as a posthumous tribute.

And, in order to fight against the metaphor of the Tower of Babel that he presents, we do so in the four official languages of our journal.

Translated by Marco Segatti

\section{THE TOWER OF BABEL}

Michele TARUfFo

It is not really clear the identity of those who lived and operated on the Tower of Babel, especially after the unfortunate event known as the "confusion of the tongues». On this matter, sources are sketchy. However, before the unfortunate event there were people of different origins and various linguistic habits. There must have been many interpreters too; for, before the unfortunate event, things were running decently well, so much so that someone was inspired to the well-known gesture of exaggerated pride.

It is reasonable to assume that there were many lawyers, if only because of the serious legal problems that arise when one builds a significant construction. Property law, administrative tenders, supply contracts, subcontracts, labor and industrial relations law, and philosophy of law (particularly in relation with the Divinity) were necessarily involved in the ordeal. They must have been polyglot lawyers (or had access to skilled translators) and expert comparative scholars, since-again according to the sources-it appears that there weren't particular problems on this score, the presence of people from the most diverse ethnic and cultural backgrounds notwithstanding.

And then came the confusion of the tongues, and it shocked everyone. The construction of the tower ended badly, as everyone knows, but that's not what matters. 
An aspect that has been neglected so far concerns the long-term consequences which the confusion of the tongues had for those who were there and for their progeny. After all, suddenly finding oneself to no longer understand the language of colleagues and collaborators must have been a tragic experience, as many of those who risk a "do-it-yourself» holiday abroad know. Again, given the known lack of direct sources, we know nothing about this not insignificant problem. However, arguing ex-post, it is possible to arrive at some plausible conclusions.

One of them is that not everyone reacted in the same way. Another is that lawyers were certainly the worst-off. But perhaps, it is better to explain on what these bold inferences are based.

Many of the professionals who were present reacted positively to the problem; or, at any rate, their successors did-sooner or later. An accurate research on the history of scientific culture might provide many details about this, but let's get to the point. The fact of the matter is that engineers, physicists, medical doctors, economics and finance wizards, traders and prostitutes rapidly learnt to understand each other anyways, even though their languages, those of their colleagues and of their clients had become different and almost incommunicable. They did it with gestures, grimaces, mathematical symbols, grunts and sighs, or by learning English, but they did it. Even more: of the conditions "prior the unfortunate event", they kept the habit of not differentiating one's capacities, values, methods, styles and results in light of his language. Worse still: they came to think that if a problem is serious, then it affects all or many, regardless the idiom of anyone. They came to think, too, that if a problem exists only for those who speak a particular idiom, then it is most likely that it is not a serious problem at all.

This tendency, when generalized, threatened the purpose that Someone had pursued with the confusion of the tongues; namely, to make communication impossible and, consequently, to make the formation of a widespread common culture, the development of large and too ambitious projects which would involve humanity as a whole, impossible too.

Only one group managed to evade the general trend, was able to avert the danger, and therefore became dear to the heart of the One who wisely judges everything: lawyers.

The confusion of the tongues, and their separation, became sacred and inviolable for them. The use of a single tongue, possibly spoken by a few, became a fundamental methodological problem. From this, a further and equally fundamental principle was logically derived. It goes something like this: «Avoid knowing what lawyers who speak another language do and say; if you can't really avoid it, do not take it into account. Know too that, if you violate this principle, you will not be very lucky in your career».

Translated by Marco Segatti 